\title{
PERFORMANCE ANALYSIS OF THREE-PHASE INVERTER USING DIFFERENT TECHNIQUES FOR THE GRID- CONNECTED PV SYSTEM
}

\author{
Laxmi Singh ${ }^{1}$, Dr. Imran ${ }^{2}$

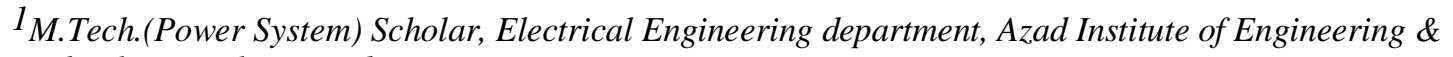 \\ Technology Lucknow, India \\ ${ }^{2}$ Assistant Professor, Electrical Engineering department, Azad Institute of Engineering \& Technology \\ Lucknow, India \\ 1Email-laxmisingh890@gmail.com \\ ²Email-pe.imran@gmail.com
}

\begin{abstract}
The model of a three-phase a voltage source inverter is examined based on space vector theory. SVPWM offers a improved outcome with the inverter as compared to the conservative SPWM technique for inverter. There is $15.5 \%$ upsurge in the line voltage of the inverter. SVPWM better exploit the available DC link power with SVPWM inverter. It has been revealed that the SVPWM method utilizes DC bus voltage extra competently and produces a smaller amount of harmonic distortion and easier digital realization in a threephase voltage-source inverter. For converter's gating signals generation, the space-vector pulse width modulation (SVPWM) strategy lessens the switching losses by restrictive the switching to the two thirds of the pulse duty cycle. A hypothetical study regarding the use of the SVPWM the three-level voltage inverter and simulation results are offered to prove the usefulness of the SVPWM in the involvement in the switching power losses lessening, output voltages with less-harmonics. Nevertheless despite all the above cited benefits that SVPWM enjoys over SPWM, SVPWM technique used in three-level inverters is more difficult on account of large number of inverter switching states. The attained simulation outcomes were satisfactory. As prospects, future experimental works will authenticate the simulation results. A software simulation model is developed in Matlab/Simulink.
\end{abstract}

Keywords: Space-Vector Pulse Width Modulation (SVPWM), Three phase Inverter system, Grid Connected PV System, Simulation Model, Matlab/Simulink

\section{INTRODUCTION}

There is urgent need to find the substitute of conventional source of energy. Energy obtained by fossil fuel is limited and affects the environment also. It gives rise in global warming. Clean power like solar, wind and hydro energy are being explored for power generation. Due to easy availability of sun, solar power generation can be done at large and small scale both. Large scale power generation will supply power to big cities and can be connected with traditional power system grid. Small scale generation can be used for household burden, motor operation, water pump etc.

The capability of the sun is enormous, but garnering it is a challenge due to the restricted efficiency of the whole system. The photovoltaic power system output low and consists of voltage and current harmonics. This study will recognize the various method to upgrade the power generation system. One of the area is array increasing and pursuing device that drives the locations solar array to prolonged solar irradiance to give maximum output. Another method is to use various versions of solar cells ranging from the earliest to the latest and analyses losses and how to lessen them. Finally, some modules that are necessary for effective process of solar energy inverter method are explored.

The use of conventional sources of power is coming down. In addition, the cost of energy is increasing and photovoltaic system may be a hopeful substitute. They are easily available, non polluting, distributed throughout the earth and eco-friendly. The hindrance factor is the high 
installation cost and low efficiency. Hence, we have to increase the proficiency of power production system. It is also important that constant voltage must be provided to the load, irrespective of the difference. PV arrays consists of arrangement of PV cells in parallel and series to produce electrical energy. It is dependent on the atmospheric situations (e.g solar irradiation and temperature) and therefore It is necessary to couple the PV array with a boost converter. Also, this system is planned in a manner that with variation in load, the alteration in input voltage and energy is fed into the converter trails through. This method will ensure continuous stepped up voltage to dc loads.

\section{PAST WORK}

India is the first to make ministry of new and renewable energy for non-conventional energy resources. Being a tropical nation India has high solar energy. The best renewable green energy source is solar energy. By 2017, the demand of power had increased from 900 billion kilowatt-hours to 1400 billion kilowatt-hours. There is already a huge gap between demand and supply. To satisfy the increased demand, solar power can be used. It is easily accessible renewable energy alternative capable of fulfilling the need of our nation. India is the fourth country after Japan, Germany and U.S to use PV availability.

Peterson K. Hinga [1] and fellows built an original multi-step PWM Inverter solar power production system. The new type of PWM inverter offered many qualities such as the decent output waveform. Smaller filter, less switching losses and muted acoustic noise. The circuit configuration, regulate method and the features of the system were defined in their paper and were also explored the relation between the inverter and the solar cell.

Martina Calais. Vassilios G. Agelidis [2] worked on dissimilar multilevel topologies and explored their suitability for single-phase grid associated photovoltaic systems. Numerous foundations of DC besides the converter make multilevel technology attractive for photovoltaic uses. They linked the Half Bridge Diode Clamped. Full Bridge Single Leg Clamped, Cascaded (CC), Step, Magnetic Coupled and Flying Capacitor (FC) multilevel converter topologies.

ChemNayar [3] and fellows showed an original power converter which was capable of mining maximumpower from solar photovoltaic plates.The proposed dual converter (combination of VCVSI and CCVSI) was capable of supplying uninterruptible power, load voltage maintenance, unity power factor process, maximum power point tracking along with reactive power provision. The total efficiency was greater than the orthodox system with a dc-dc converter in the PV panels along with the battery.

In [4] proposed a new three phase active commutated thyristors current source inverter (CSI) topology for grid linked photovoltaic systems. The simple active commutated thyristor CSI which had pulse width modulation (PWM) feature was built with a resistive load. To overcome the normal frequency of oscillations of the LC filter and to protect the stability of the system, a charge controller with synchronous rotary reference frame was developed. It allowed relaxed strategy of PI controller gains.

Anastasios Ch. Kyritsis, Nikolaos P. Papanikolaou [5] and fellows advanced a different plan and control scheme of the Fly back Inverter for devolved grid linked PV systems. It achieved a high power density and efficiency, along with high power factor rule. The project and control scheme was explored to developed a converter with the least potential volume for an assumed power and to the intensification of the power transmission for assumed converter limits. Being different from a standard converter topology this system offered a very high efficiency because of its simplified 
arrangement.

Qingrong Zeng, Liuchen Chang [6] worked on Space vector pulse-width modulation which is largely used in existing control of three-phase voltage-source inverters. In grid- connected circulated generation schemes, SVPWM is unsuitable in existing controllers, such as the case of bargained output current because of the grid harmonic trouble and nonlinearity of the scheme and also the absence of essential over-current shield. There is a enactment due to influence of the grid harmonics. It also comprises overr-current safety to the system.

Juan Jose Negroni, FrancescGuinjoan [7] and fellows described the analysis, modelling and proposal of a Buck-based inverter regulator for grid-connected photovoltaic (PV) systems. On one hand a linear digital voltage manager is planned from a large-signal linear sampled-data classical of the system to make best use of the steady state input- output energy transmission percentage. On the other hand, a sliding-mode current controller is similarly planned to reassure a unity power factor.

Yi Huang, Miaosen Shen [8] suggested a Z-Source inverter structure for a split-phase grid-associated photovoltaic system. As a result of the development of solar cell technology, the price of solar modules has fallen intensely. To lesser the cost of the PCSs had been a very crucial issue of grid connected PV systems. By using the Z - source inverter, the amount of switching modules and the whole volume of the system can be lessened. All the benefits of the Z-source inverter and the sixswitch split-phase inverter are natural and combined composed to create a highly dependable PCS system with diminished volume and cost.

Yang Chen, Keyue Smedley and Jack Brouwer [9] determined that the utilization of solar energy the convenience grid infrastructure for power broadcast and circulation, grid connected dc-to-ac inverters is desirable for solar power generation. Thus a economical MPPT technique integrated inside the OneCycle Control (OCC) core has projected. There is no power intention in the controller; it harvests a humble and economical explanation and compact the circuit difficulty, power losses.

\section{SOLAR ENERGY AND PHOTOVOLTAIC SYSTEM}

\section{A. Solar Energy}

Solar power is a non-conventional kind of power. Solar energy has been yoked by individuals since earliest times by means of a diversity of technologies. Solar radiation, alongside with secondary solarpowered assets such as wave and wind control, hydroelectricity and biomass, reason for most of the accessible non-conventional type of power on earth. Only a small portion of the obtainable solar energy is used.

Solar power-driven electrical generation depend on photovoltaic system and heat machines. Solar energy's uses are inadequate only by human creativity. To yield the solar power, the most usual way is to use photo voltaic panels which will obtain photon energy from sun and transform to electrical power. Solar technologies are broadly classified as either passive solar or active solar dependent on the way they keep, translate and dispense solar power. Active solar methods contain the usage of PV panels and solar thermal gatherers to band up the energy. Passive solar techniques comprise positioning a building to the Sun, choosing ingredients with advantageous thermal mass or light scattering possessions and scheme spaces that obviously circulate air. Solar energy has a massive space of use such as electricity generation for distribution, warming water, lightening construction, 
harvest ventilation etc.

\section{B. Distribution of Solar Radiation}

From the above Figure 3.1 of solar radiation, Earth receives 174 peta watts (PW) of arriving solar radiation at the higher troposphere. About $30 \%$ is reflected back to space and only $89 \mathrm{pw}$ is captivated by oceans and land masses. The range of solar light at the Earth's surface is usually feast across the noticeable and near-infrared reason with a minor share in the near-ultraviolet. The entire solar energy captivated by Earth's atmosphere, oceans and land masses is around 3,850,000 EJ per year.

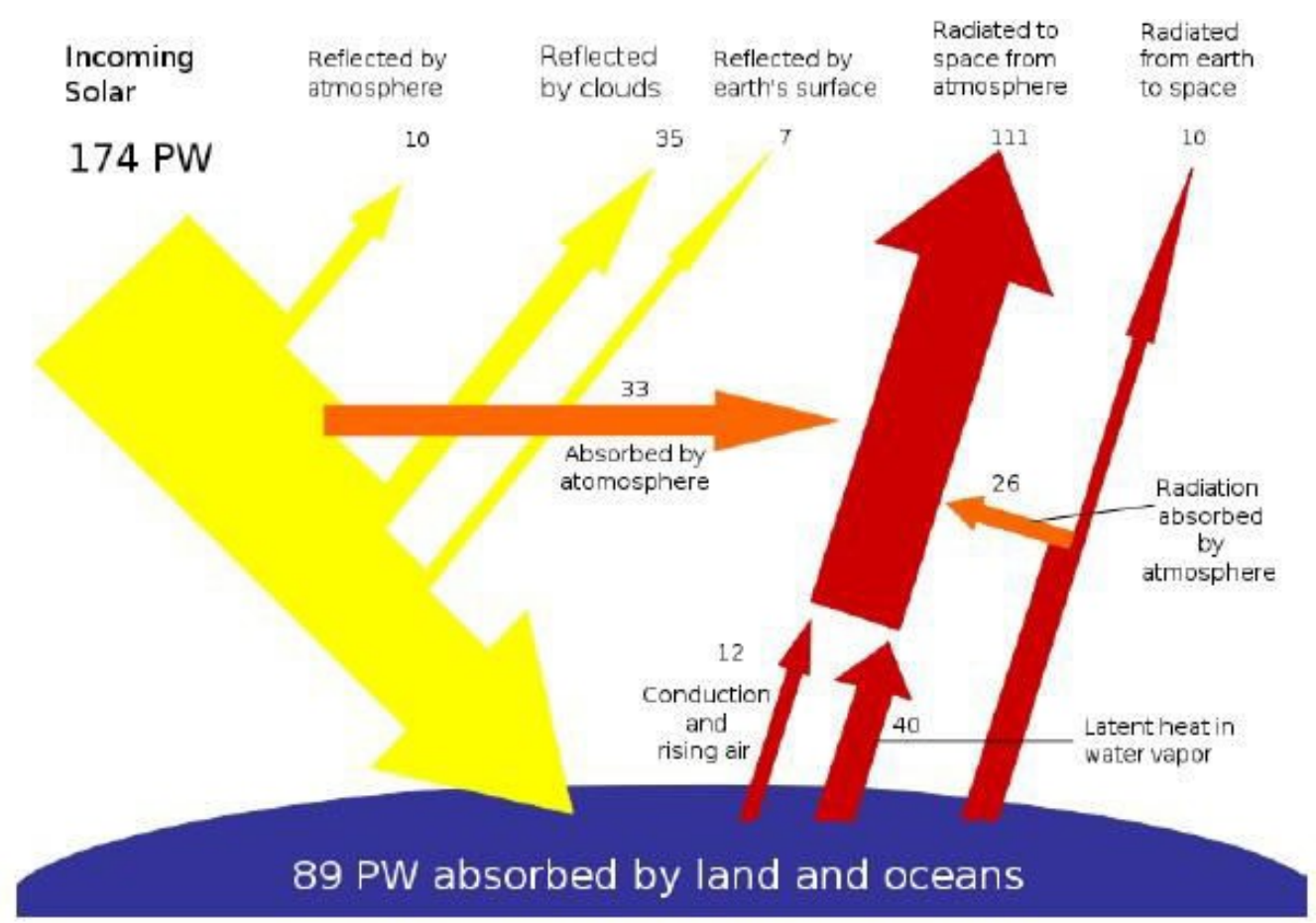

Figure 3.1 Solar radiations spreading.

The concentration of solar radiation reaching ground surface which is 1369 watts per square meter is recognized as Solar Constant. It is significant to understand that it is not the intensity per square meter of the Earth's surface but per square meter on a sphere with the radius of 149,596,000 km and with the Sun at its epicenter.

\section{Photovoltaic System}

A photovoltaic scheme is a method that practices one or more solar panels to transform solar power into electricity. It comprises of numerous components, containing the photovoltaic modules, mechanical and electrical connections and mountings and means of changeable and/or adjusting the electrical output.

\section{Photovoltaic arrangement}




\section{a. Photovoltaic cell}

PV cells are prepared of semiconductor ingredients, for example silicon. For solar cells, a thin semiconductor wafer is particularly preserved to form an electric field, positive on one side and negative on the other. When sun energy raids the solar cell, electrons are hit moveable from the atoms in the semiconductor factual. If electrical conductors are involved to the positive and negative sides, creating an electrical circuit, the electrons can be seized in the form of an electric current - that is, electricity. This electricity can then be used to power a load. A PV cell can either be spherical or square

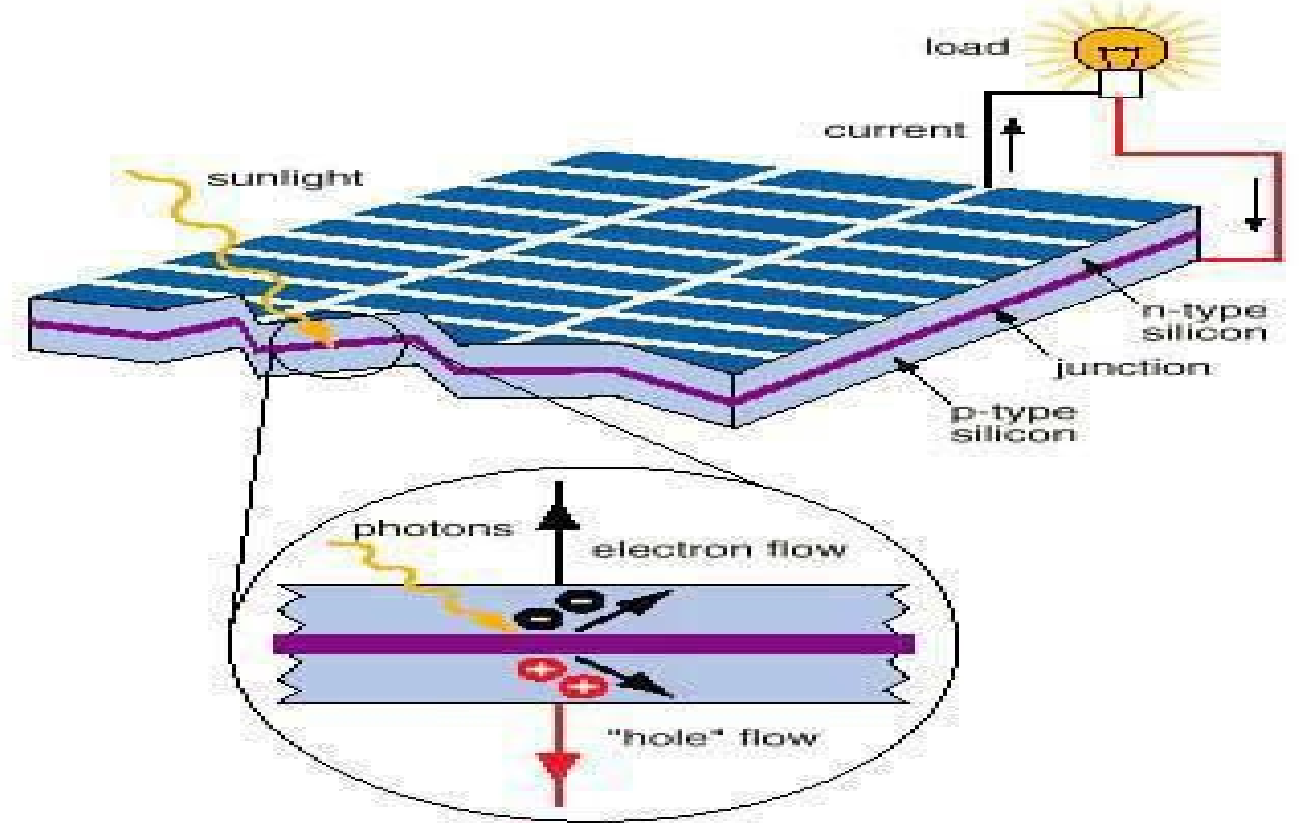

Figure 3.2: Basic Structure of PV Cell

\section{b. Photovoltaic module}

Because of the low voltage produced in a PV cell (around 0.5V), numerous PV cells are connected in series (for high voltage) and in parallel (for high current) to form a PV module for preferred output. Distinct diodes may be wanted to avoid reverse currents, in case of incomplete or total shading, and at night. The p-n junctions of mono- crystalline silicon cells may have satisfactory reverse current features and these are not needed. Reverse currents waste power and can also hint to warmness of shaded cells. Solar cells become less effective at greater temperatures and installers try to deliver good airing behind solar panels.

\section{c. Photovoltaic array}

The power that one module can generate is not adequate to see the necessities of home or industry. Most PV arrays use an inverter to transform the DC power into alternating current that can power the motors, loads, lights etc. The modules in a PV array are typically first linked in series to attain the preferred voltages; the separate modules are then linked in parallel to let the scheme to generate additional current. 

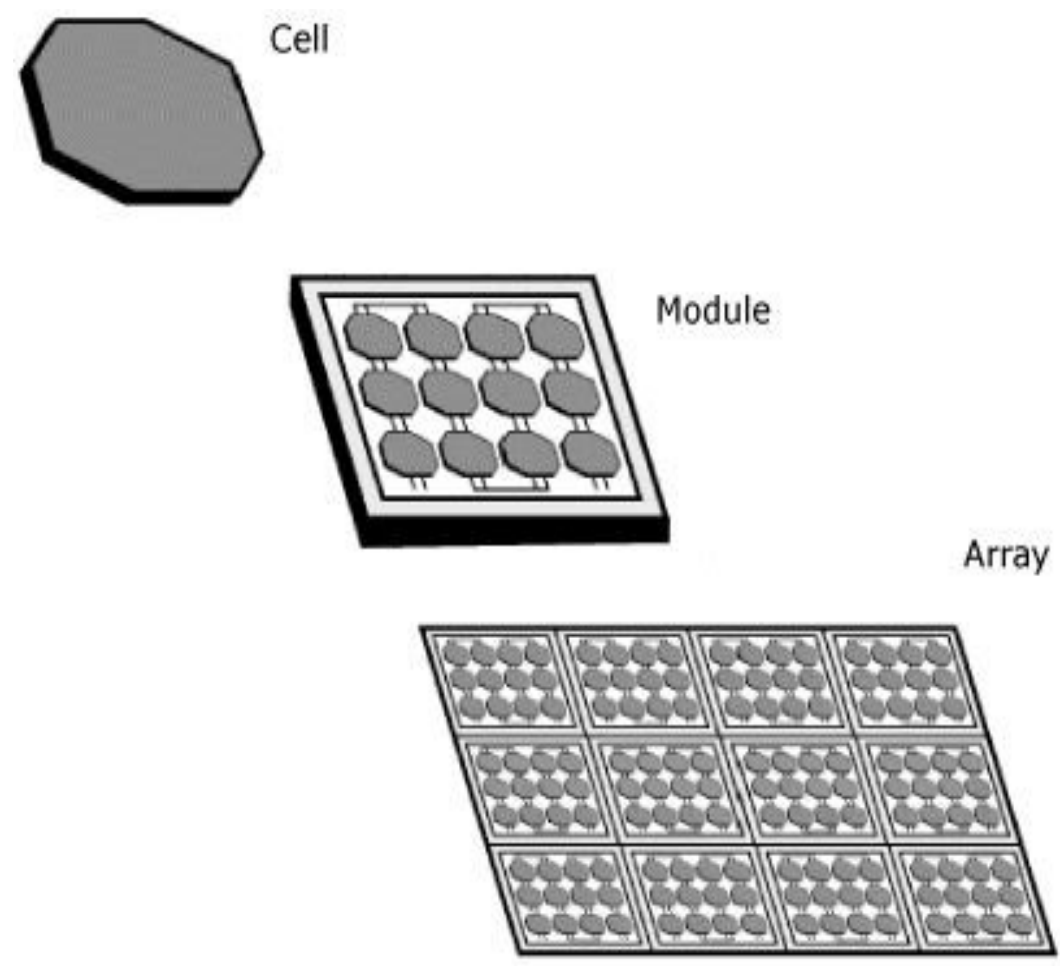

Figure 3.3 Photovoltaic structure

\section{d. Characteristics of PV cell}

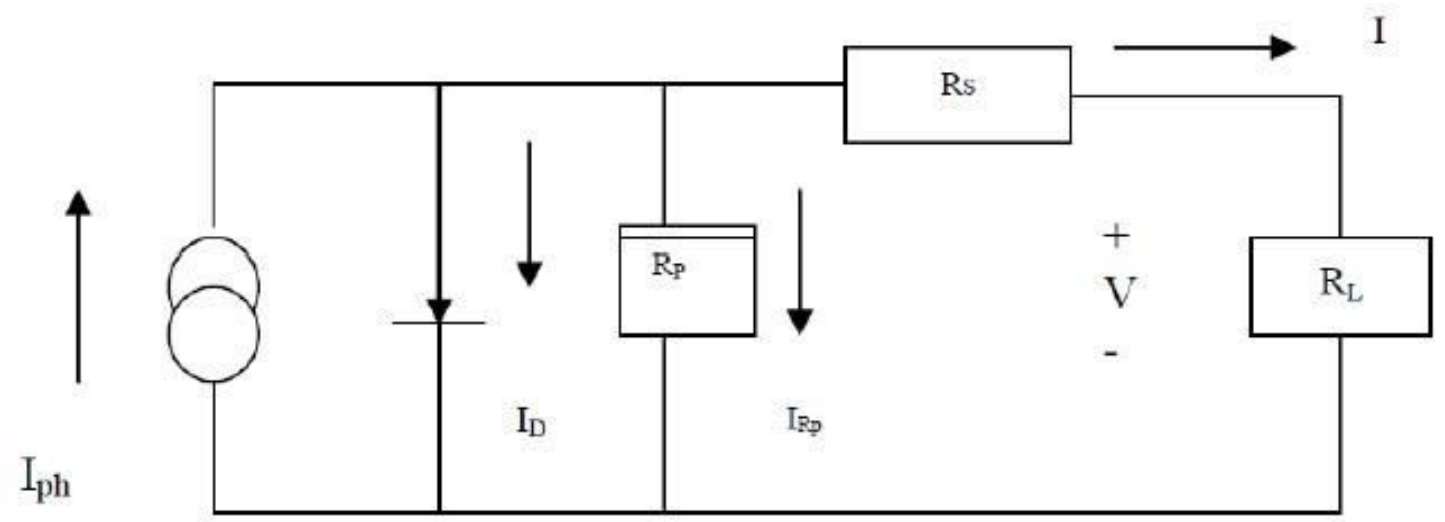

Figure 3.4: Corresponding circuit of a PV cell

An ideal is demonstrated by a current source in parallel with a diode. Though no solar cell is perfect and thus shunts and series resistances are additional to the model as shown in the PV cell diagram above. RS is the inherent series resistance whose worth is very minor. $\mathrm{R}_{\mathrm{SH}}$ is the equivalent shunt resistance that has a very high significance.

\section{POWER ELECTRONICS CONVERTERS AND CONTROL DEVICES}

Since as a result of rising demand of electrical power and debauched, dependable and carefully power 
flow control purposes, distinct control strategies are required. This chapter stretches an impression of Power Flow Regulatory Devices, categories of devices, functioning principles and the benefits and restrictions of each device.

\section{A. DC-DC Converters}

DC-DC converters can be applied as switching mode controllers to transform an uncontrolled dc voltage to a controlled dc output voltage. The directive is normally attained by PWM at a static frequency and the switching device is usually BJT, MOSFET or IGBT. The least oscillator frequency should be around 100 times lengthier than the transistor switching time to make the most of efficiency. This drawback is caused by the switching loss in the transistor. The transistor switching loss upsurges with the switching frequency and thus, the productivity declines. The core loss of the inductors bounds the high frequency process. Control voltage Vc is gained by linking the output voltage with its wanted value. Then the output voltage can be equated with its anticipated value to achieve the control voltage Vcr. The PWM control signal for the dc converter is produced by associating Vcr with a saw tooth voltage Vr. There are four topologies for the switching regulators: buck converter, boost converter, buck-boost converter, cứk converter. Though this project work pacts with the boost regulator and additional thoughts will be focused towards this one.

\section{B. Boost Converter and its Operation}

The figure (4.1) below shows a step up or PWM boost converter. It comprises of a dc input voltage source Vg, boost inductor L, controlled switch S, diode D, filter capacitor C, and the load resistance $\mathrm{R}$. When the switch $\mathrm{S}$ is in the on state, the current in the boost inductor upsurges linearly and the diode $\mathrm{D}$ is off at that time. When the switch $\mathrm{S}$ is turned off, the energy stored in the inductor is unrestricted through the diode to the output RC circuit.

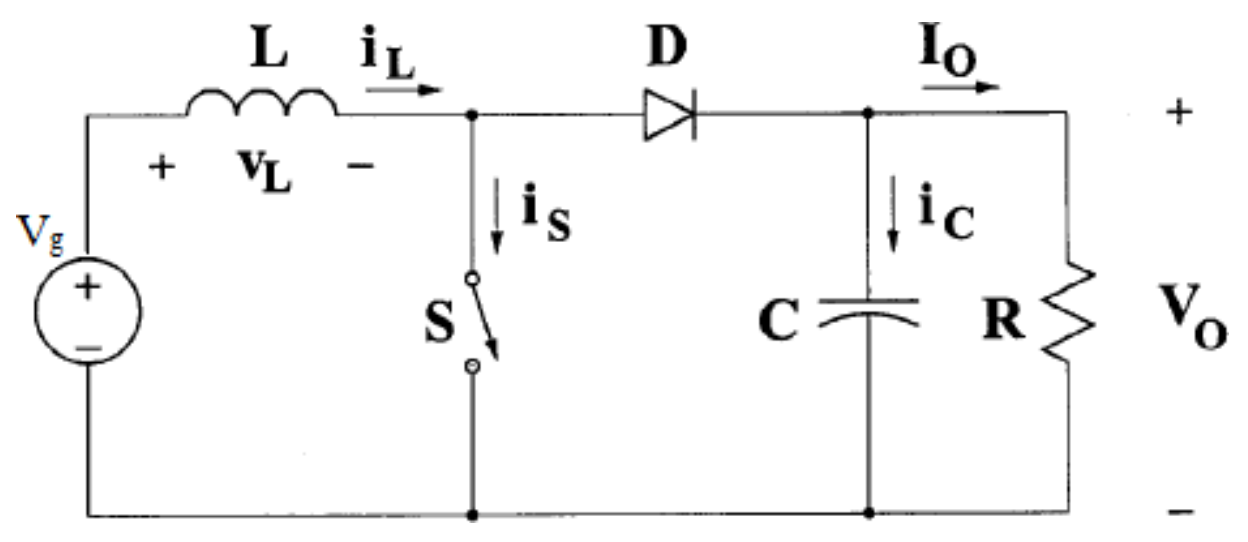

Figure 4.1 Circuit diagram of boost converter

\section{DC-AC Converters}

A DC-AC converter or inverter is a semiconductor devices centered circuit that transforms dc input voltage to ac output power. Semiconductor diodes are used widely in power electronic circuit for the transformation of power from dc to ac. An inverter retaining diodes is called as unrestrained inverter; due to its average output voltage is stationary ac voltage. Physically, inverter take numerous forms, counting vacuum tube diodes, mercury-arc valves, copper and selenium oxide rectifiers, 
semiconductor diodes, silicon-controlled rectifiers and other silicon-based semiconductor switches. Formerly synchronous electromechanical (M-G) switches and engines have been used.

\section{Voltage Source Inverters}

The core aim of static power converters is to generate an ac output waveform from a dc power supply. These are the kinds of waveforms essential in adjustable speed drives (ASDs), uninterruptible power supplies (UPS), static vary compensators, active filters, flexible ac transmission systems (FACTS), and voltage compensators, which are only a few uses. For sinusoidal ac outputs, the magnitude, frequency, and phase should be manageable.

\section{E. Single-Phase Voltage Source Inverters}

Single-phase voltage source inverters (VSIs) can be originating as half-bridge also full- bridge topologies. Though the power variety they protect is the little one, they are extensively used in power supplies, single-phase UPSs, and presently to form elaborate high-power fixed power topologies, for instance, the multi cell configurations.

\section{SPACE VECTOR PULSE WIDTH MODULATON FOR THREE PHASE INVERTER}

Space vector PWM (SVPWM) is a more refined method for producing a fundamental sinusoidal wave that delivers a greater voltage to the load and lower total harmonics distortion. Nevertheless, the conventional Direct Current/ Alternate Current (DC-AC) method has the draw backs for instance low utilization of DC voltage, tough operation voltage and high harmonics substance, which cannot meet the necessities of inverter. The SVPWM can be operational to resolve these glitches and get greater inverter application of DC voltage and lower harmonic matters.

\section{A. Operation Principle of SVPWM}

The topology of a three-leg voltage source inverter is presented in Fig. 5.1. Since the restriction that the input lines essentially never be shorted and the output current must permanently be continuous a voltage source inverter can accept only eight distinct topologies. These topologies are displayed on Fig. 5.2. Six out of these eight topologies create a nonzero output voltage and are recognized as nonzero switching states and the left behind two topologies produce zero output voltage and are recognized as zero switching states. 


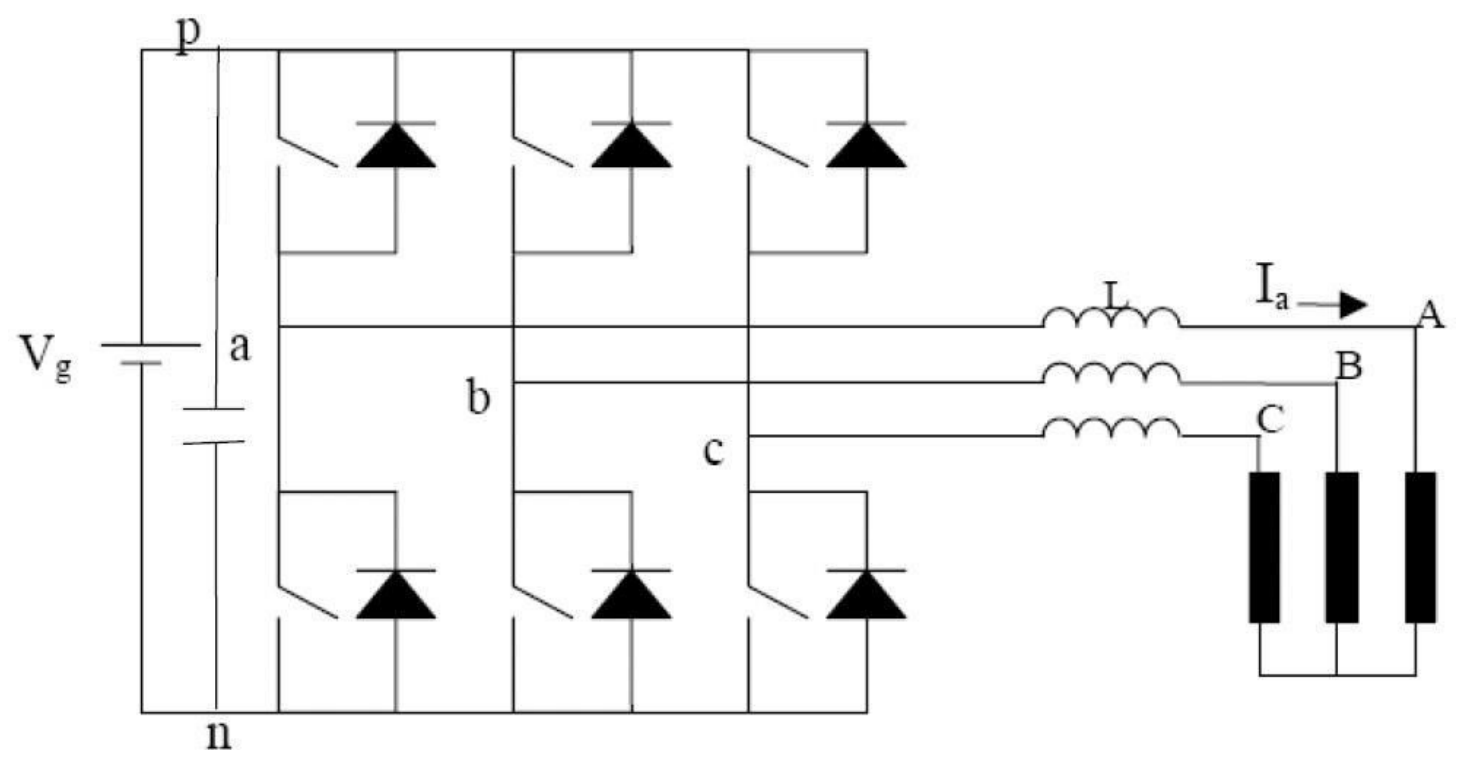

Figure 5.1: Topology of a three-leg voltage source inverter
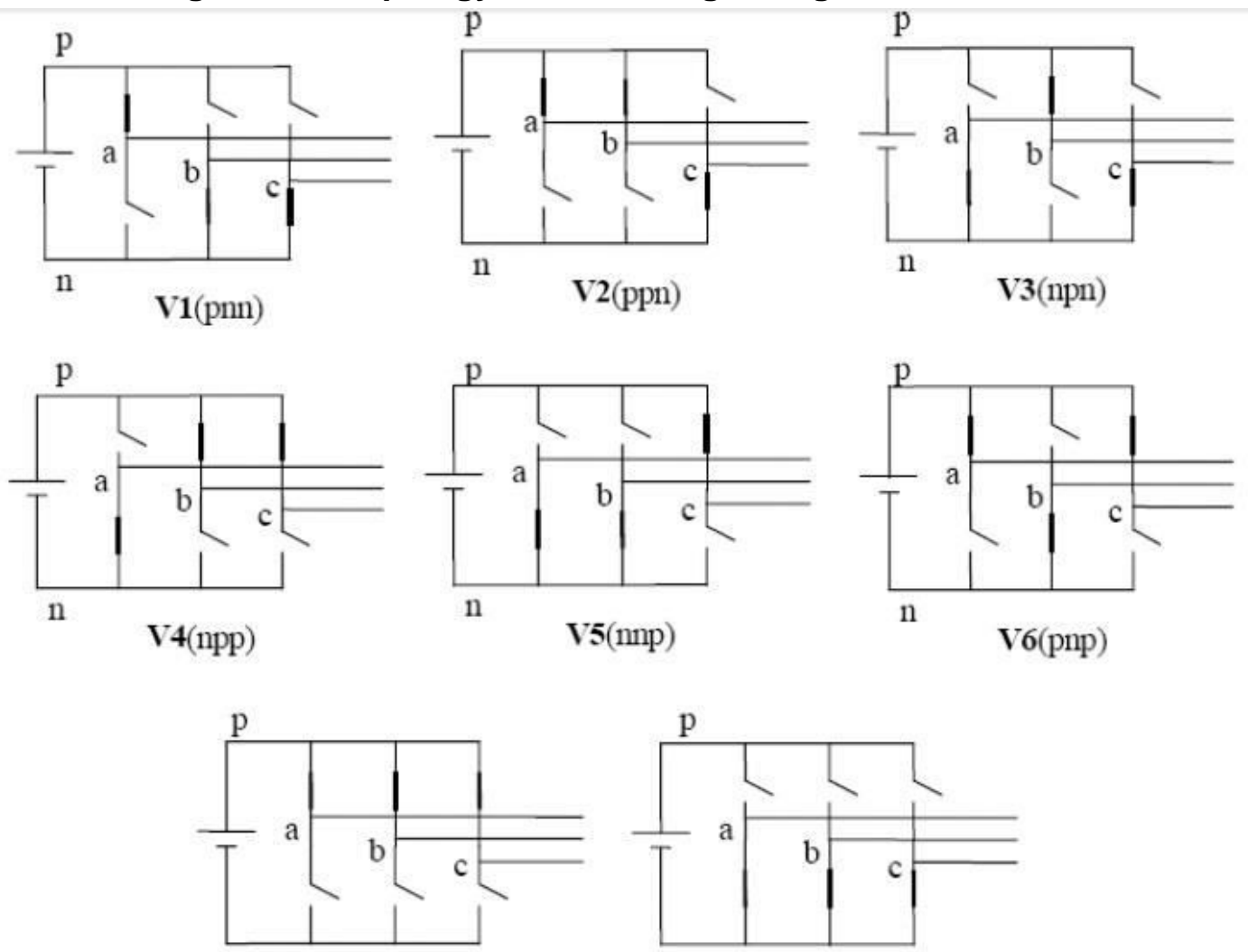

Figure 5.2: Eight switching state topologies of a voltage source inverter. 


\section{SIMULATION AND TEST RESULTS}

\section{A. Test Systems}

Figure 6.1 is a simulation diagram of a photovoltaic array producing power extracted from the solar energy.
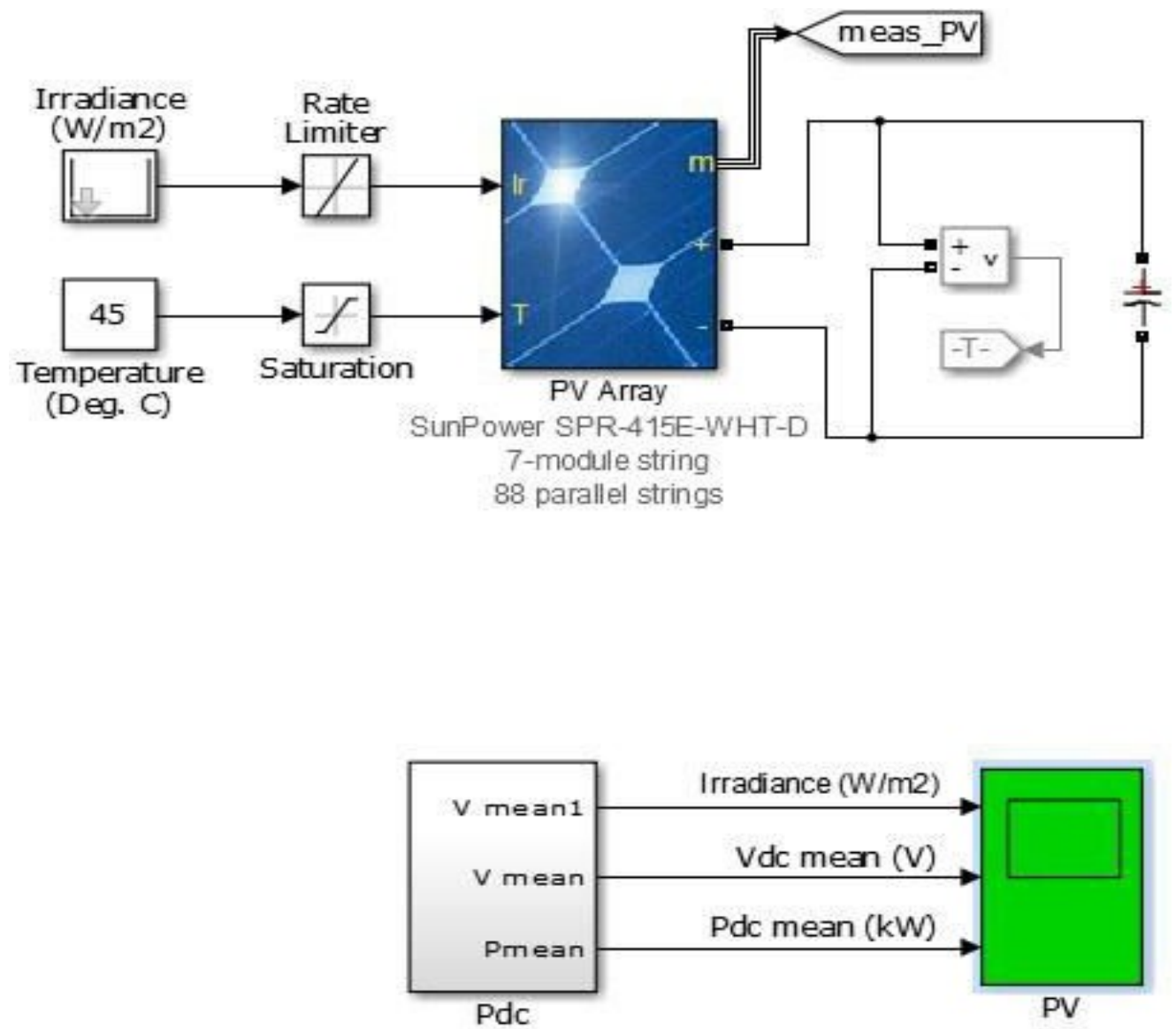

Discrete,

$T_{5}=5.051 \mathrm{e}-06 \mathrm{~s}$

Figure 6.1: Simulation diagram of proposed converter

A photovoltaic array used for the production of power from the solar energy consist of numerous photovoltaic cells arranged in combination of series and parallel. The output potential produced from the photovoltaic is in dc from. The power of the system can be increased or decreased on the basis of number of cell combination used.

Since the operation of PV array also depends on the temperature therefore it is important to describe threshold temperature limit. To exemplifying the design viability of projected photovoltaic array, a model outline of arrangement is chosen: 
Table 1 Parameter and Data Used In Simulink Model

\begin{tabular}{|l|l|l|}
\hline S.No. & Parameter Used For Simulation Circuit & Data \\
\hline 1 & Irradiance & $1000 \mathrm{w} / \mathrm{m}^{2} ;$ \\
\hline 2 & Temperature limit & \\
\hline 3 & Parallel string & {$[4525]$ deg.C; } \\
\hline 4 & Series connected module per string & $7 ;$ \\
\hline 5 & Cells per module & $88 ;$ \\
\hline 6 & Open circuit voltage (Voc) & $128 ;$ \\
\hline 7 & Short circuit current (Isc) & $85.3 \mathrm{~V}$ \\
\hline 8 & Shunt Resistance Rsh & $6.09 \mathrm{~A}$ \\
\hline 9 & Series Resistance Rse & $419.7813 \mathrm{ohm}$ \\
\hline
\end{tabular}

The I-V and P-V qualities of the photovoltaic array module is displayed in figure 6.1. I- V characteristics show the variation of photovoltaic module current with respect to variation in the voltage at different temperature. Similarly, P-V characteristics show the variation of photovoltaic module power with respect to variation in the voltage at different temperature.

The production from the photovoltaic array are as:

Vmean $=568 \mathrm{~V}$ Pmean $=103 \mathrm{KW}$ 

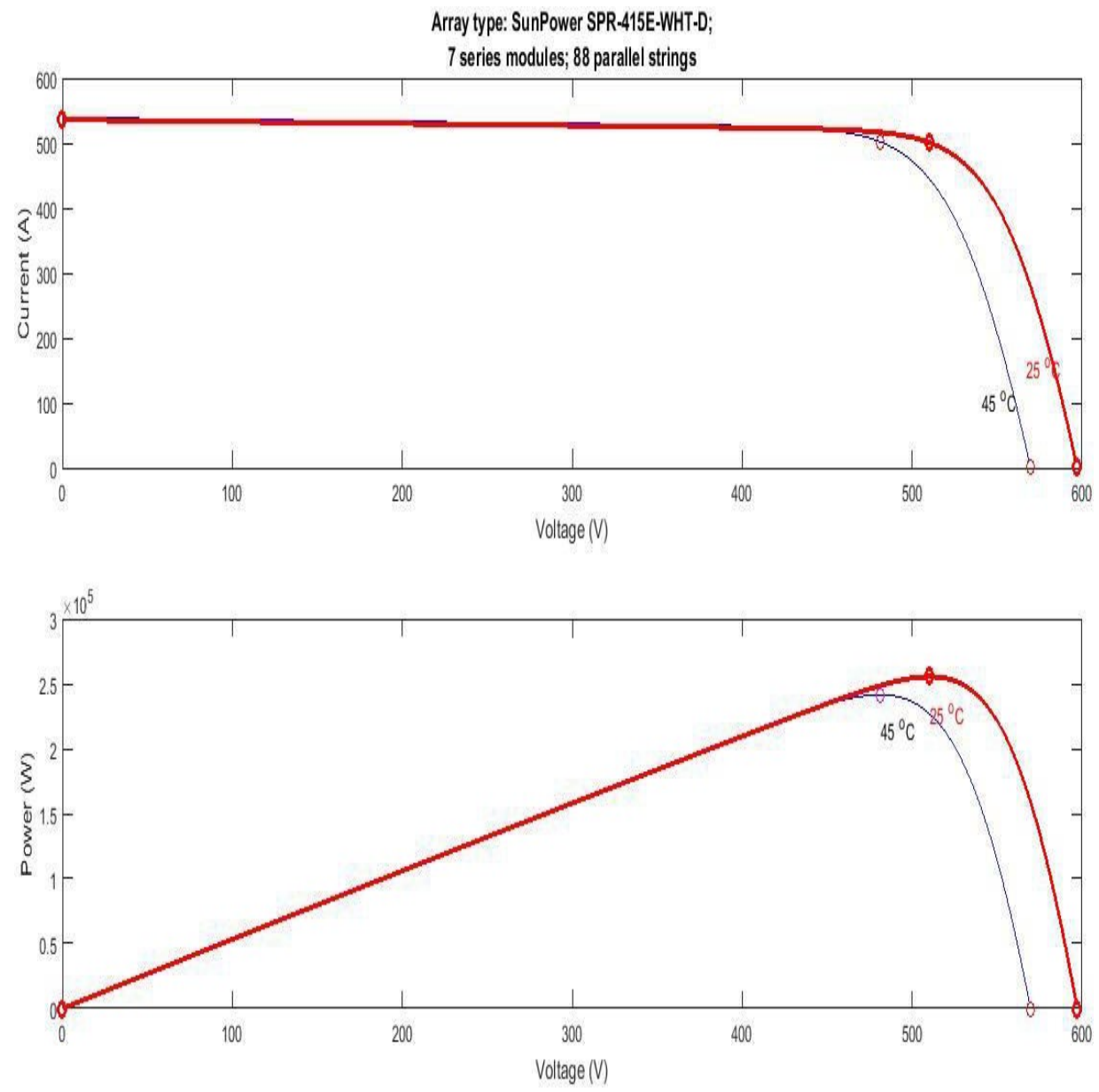

Figure 6.2 I-V and P-V characteristics of PV module

The output power and voltage produced from the photovoltaic array with the above parameters are given below in figure 6.2, 6.3, 6.4, 6.5.

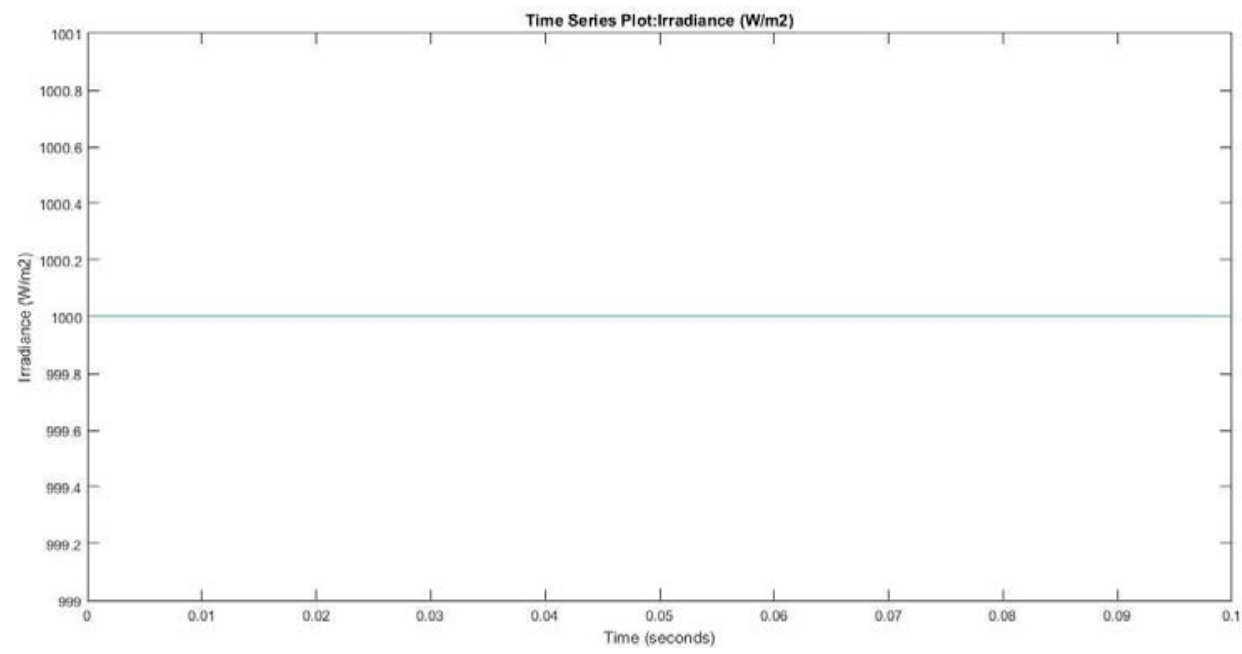

Figure 6.3 Irradiance $\mathrm{w} / \mathrm{m}^{2}$ 


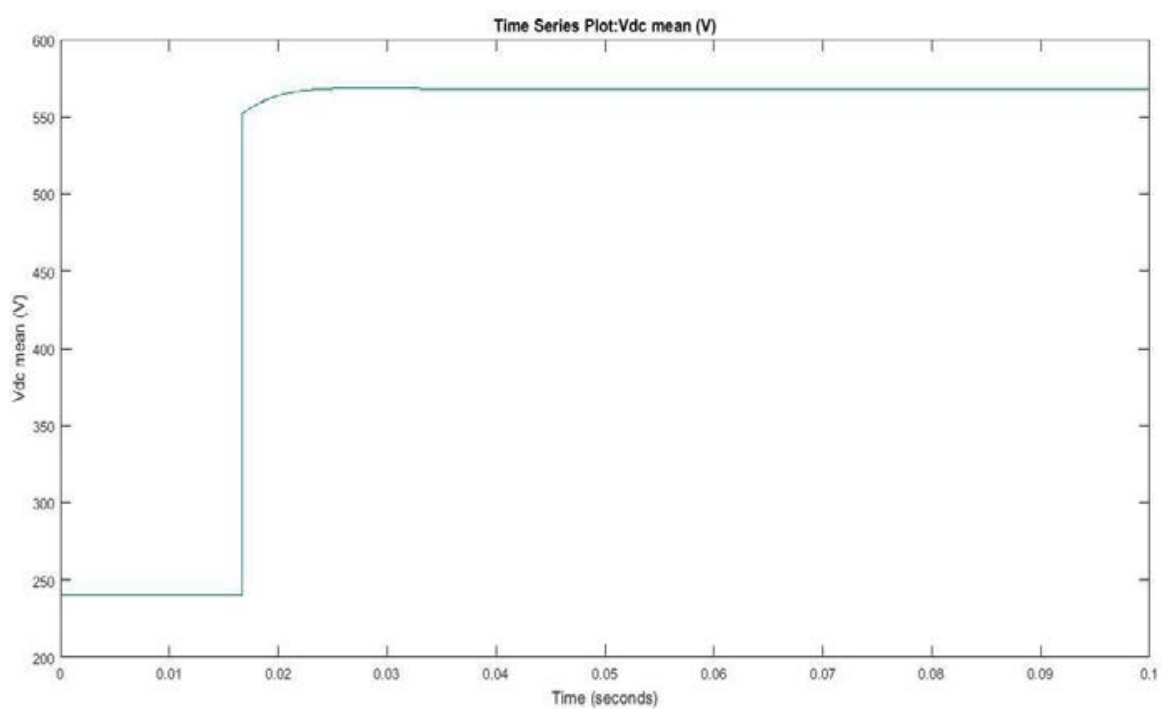

Figure 6.4 PV output voltage mean Vmean

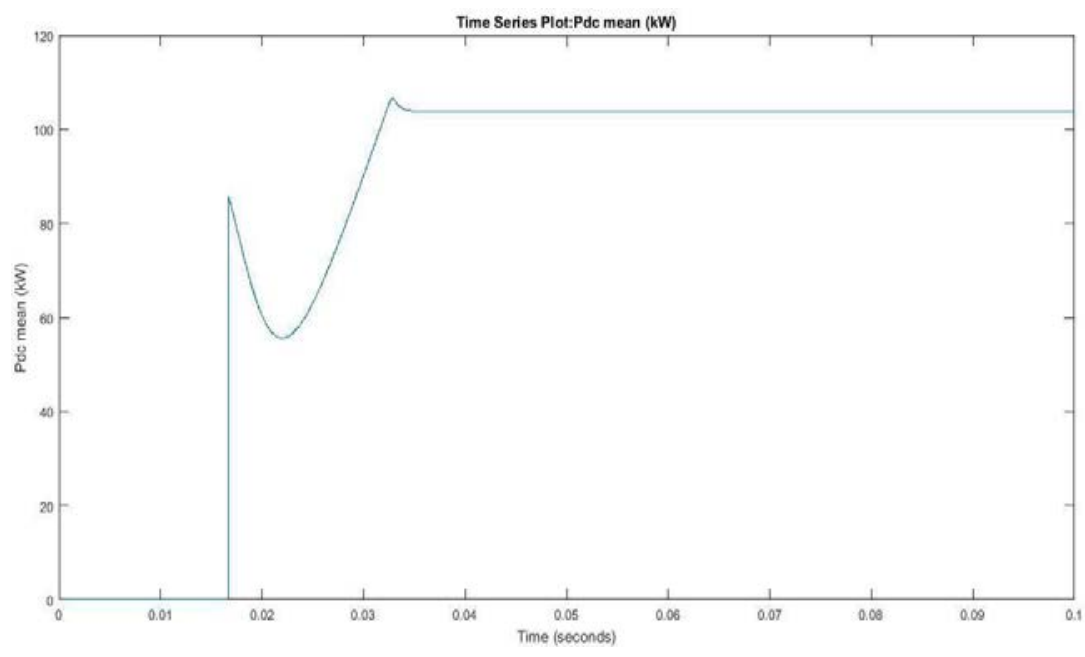

Figure 6.5 PV output mean power Pmean 


\section{B. PV array with sinusoidal PWM based three phase inverter}

Figure 5.6 is a simulation diagram of sinusoidal PWM centered three phase inverter with boost dc -dc converter used at the start for a significant increase in the dc output of the PV array. Simulink model is used here to get required output.

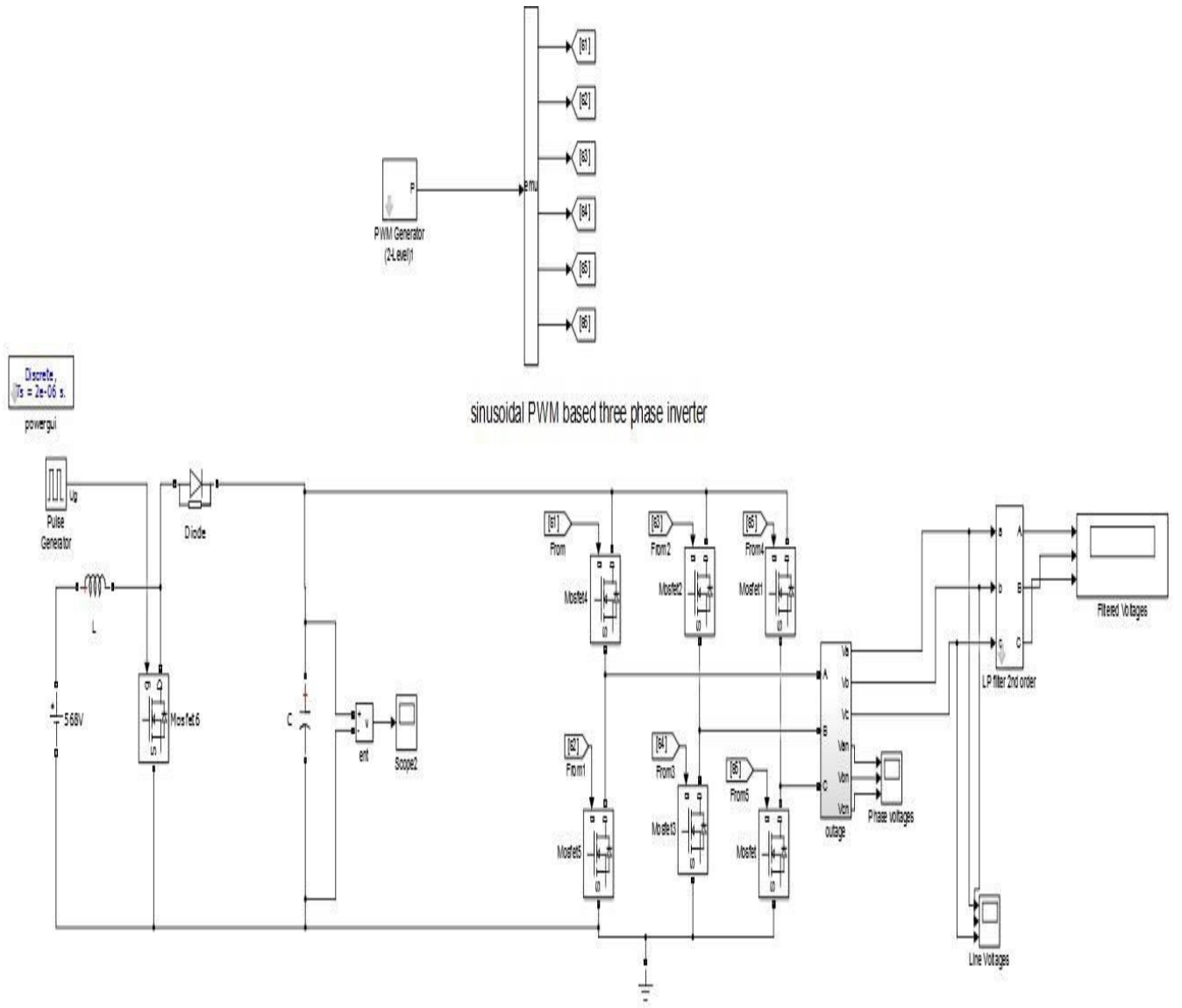

Figure 6.6Simulink diagram of sinusoidal PWM three phase inverter

Figure 6.6 demonstrations the simulation of boost dc-dc converter with configuration and specification as shown in table 2 . 


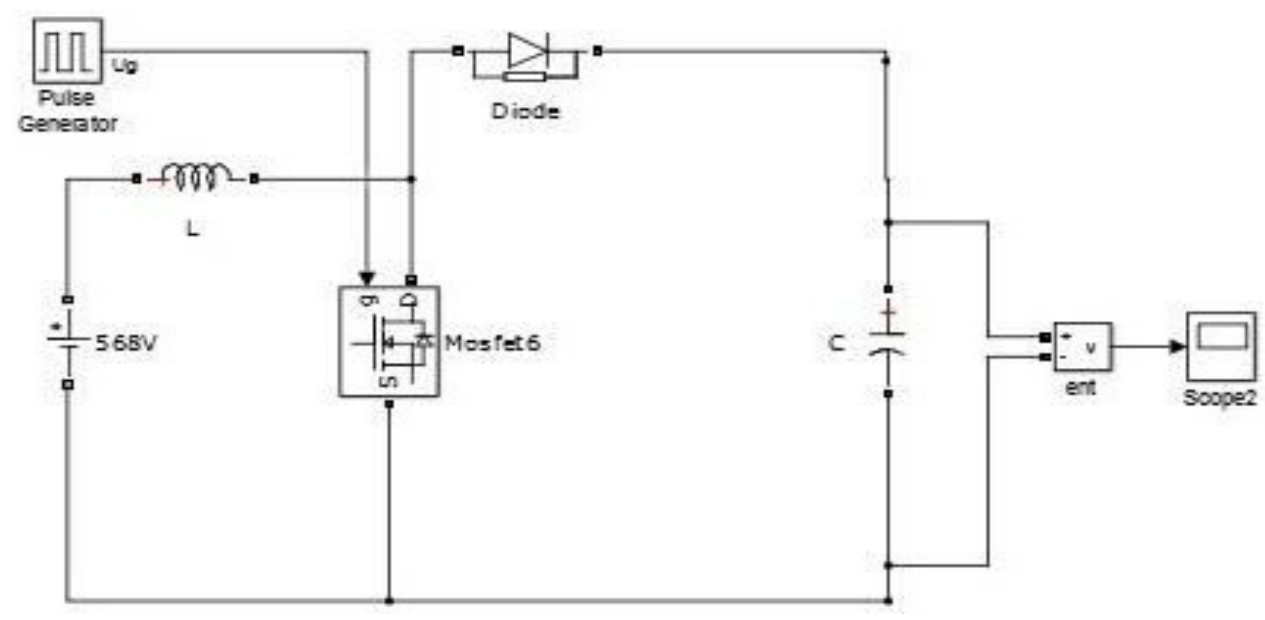

Figure 6.7 simulation model of boost dc-dc converter

Table 2 parameters and data used in boost converter

\begin{tabular}{|l|l|l|}
\hline S.No & Parameter used in simulation & Data \\
\hline 1 & Input voltage from PV array & $568 \mathrm{~V}$ \\
\hline 2 & Inductance & $0.625^{*} 10^{-6}$ henry \\
\hline 3 & Capacitance & $2.5^{*} 10^{-3}$ \\
\hline 4 & Pulse period & $1 * 10^{-5}$ secs \\
\hline 5 & Pulse width & $80 \%$ of period \\
\hline
\end{tabular}

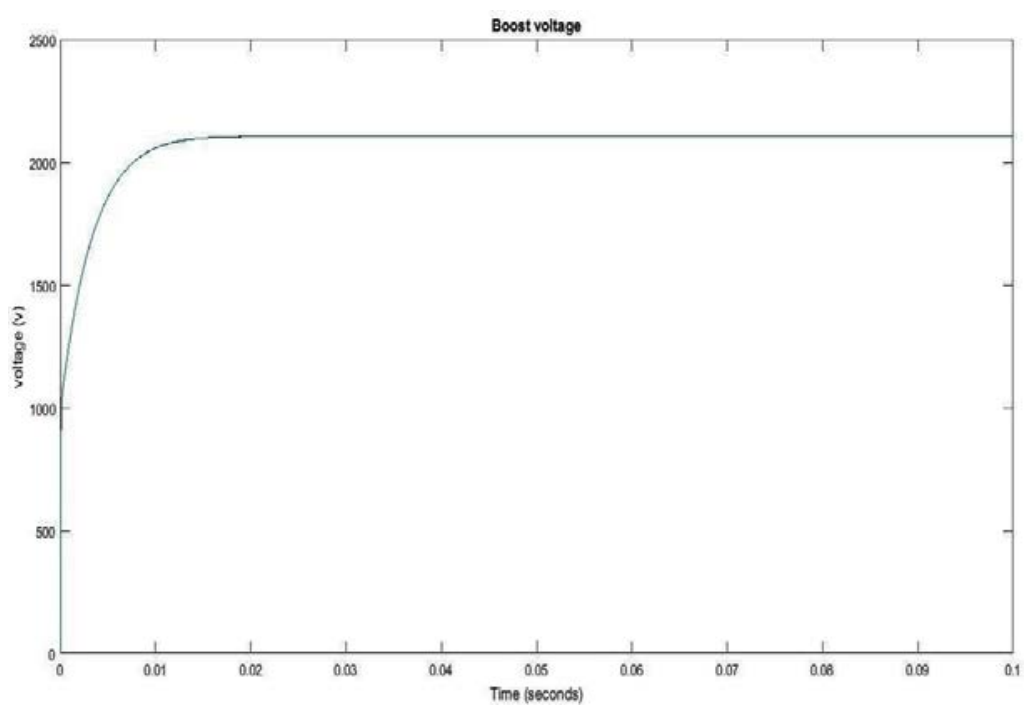

Figure 6.8 output waveform of boost dc-dc converter

\section{Space vector PWM based three phase inverter}

Figure 6.8 shows the MATLAB simulation of the space vector PWM based three phase inverter. Three phase input sinusoidal voltage is generated using the functional block of sin wave block. 

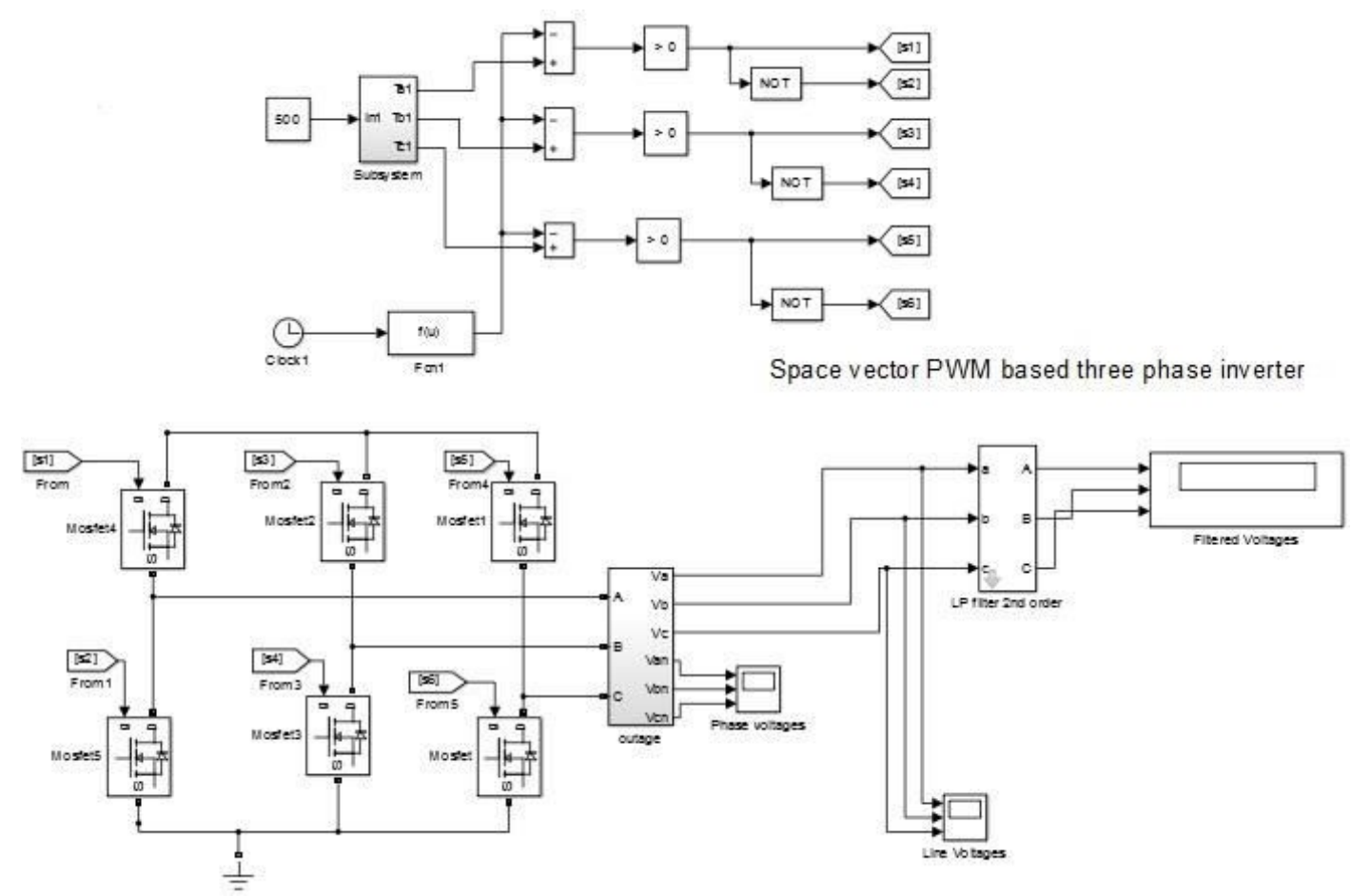

Figure 6.9: simulation model of space vector PWM based three phase inverter

\section{CONCLUSIONS}

The review has covered a few diverse inverter topologies for photovoltaic uses. The mission for such an inverter is to increase the photovoltaic low voltage up to the greater- level voltage of the grid and to convert it from DC into AC. Furthermore, the three- phase voltage source inverter should be designed with Space Vector Modulation (SVM) as switching arrangement by using MATLAB/Simulink for the grid-connected PV system. The theory of the Space Vector Modulation for a 3-phase inverter is presented by this thesis. This theory has been further extended to other 3phase converter systems and nowadays became a standard for industry. The model of a three-phase a voltage source inverter is examined based on space vector theory. SVPWM offers a improved outcome with the inverter as compared to the conservative SPWM technique for inverter. There is $15.5 \%$ upsurge in the line voltage of the inverter. SVPWM better exploit the available DC link power with SVPWM inverter. It has been revealed that the SVPWM method utilizes DC bus voltage extra competently and produces a smaller amount of harmonic distortion and easier digital realization in a three- phase voltage-source inverter. For converter's gating signals generation, the space- vector pulse width modulation (SVPWM) strategy lessens the switching losses by restrictive the switching to the two thirds of the pulse duty cycle. A hypothetical study regarding the use of the SVPWM the threelevel voltage inverter and simulation results are offered to prove the usefulness of the SVPWM in the involvement in the switching power losses lessening, output voltages with less-harmonics. Nevertheless despite all the above cited benefits that SVPWM enjoys over SPWM, SVPWM 
technique used in three- level inverters is more difficult on account of large number of inverter switching states. The attained simulation outcomes were satisfactory. As prospects, future experimental works will authenticate the simulation results.

\section{References}

[1.] Peterson K. Hinga. Tokuo Ohnishi and Takayuki Suzuki, “A New PWM Inverter for Photovoltaic Power Generation System". IEEE Conference on Power Electronics Specialists. Vol. 1. pp: 391-395. 1994.

[2.] Martina Calais. Vassilios G. Agelidis. "Multilevel Converters for Single-Phase Grid connected Photovoltaic Systems-An Overview'“. IEEE International Symposium on Industrial Electronics. pp: 224-229. 1998.

[3.] HcomanDehbonei, ChemNayar. Lawrence Borle. "A Combined VoltageControlled and Current Controlled 'Dual Converter for a Weak Grid ConnectedPhotovoltaic System with Battery Energy Storage". IEEE Conference 011 Power Electronics Specialists. Vol. 3. pp: 1495-1500. 2002.

[4.] J. S. Siva Prasad and B. G. Femandes_. "Active Commutated Thyristors CS1 for Grid Connected Photovoltaic Applications". The 4m International Conference onPower Electronics and Motion Control. Vol. 3, pp: 1767-1771. 2004.

[5.] Anastasios Ch. Kyritsis. Nikolaos P. Papanikolaou. "Design and control of acurrent source flyback inverter for decentralized grid connected photovoltaicsystems." European Conference on Power Electronics and Applications. pp: p.1-p.10, 2005.

[6.] Qingrong Zeng. Liuchen Chang. "Novel SVPWM Based Predictive Current Controller' for Threephase Grid Connected Inverters". Canadian Conference onElectrical and Computer Engineering. pp: 1262-1265. 2005.

[7.] Juan Jose Negroni. Carlos Meza. Domingo Biel. “Control of a Buck Inverter forGrid- Connected PV Systems: a Digital and Sliding Mode Control Approach ".IEEE International Symposium on Industrial Electronic. Vol. 2. pp: 739- 744.2005.

[8.] Yi Huang, MiaosenSlien and Iin Wang. "Z-Source Inverter for ResidentialPhotovoltaic Systems". IEEE Transaction on Power Electronics. Vol.21. No. 6,pp: 1176-1782,2006

[9.] Yang Chen, Keyue Smedley, "A Cost-effective Three-phase Grid- connectedInverter with Maximum Power Point Tracking". IEEE Conference on Industrial Applications (41st IAS annual meeting). Vol.2. pp: 995-1000. 2006.

[10.] HoormanDehhonei and C.V. Nayar, "A Grid-Connected Photovoltaic System withDirect Coupled Power Quality Control". 32nd IEEE Annual Conference onIndustrial Electronics. pp: 52035208, 2006. 